\title{
TOXIC SUBSTANCES OF EUPHORBIACEAE
}

\author{
YOSHIMASA HiRATA \\ Department of Chemistry, Faculty of Science, Nagoya University, Japan
}

\begin{abstract}
The multitude of physiologically active alkaloids derived from Daphniphyllum species are shown to belong to five related skeletal groups. Chemical interrelation of the daphniphylline and daphnilactone types has been achieved. Speculation concerning the biosynthesis of these alkaloids from squalene is outlined. Biosynthetic studies using labelled mevalonate and squalene which support these hypotheses are described.

Determination of structure of a variety of highly oxygenated diterpenes from Euphorbia spp. having carcinogenic, toxic, analgesic and anti-writhing activities is described.

Comparison is made between these highly oxygenated terpenes and other oxygen-rich toxic substances from Euonymus spp., the unusual $\beta$-lactones anisatin and neoanisatin and tetrodotoxin.
\end{abstract}

\section{INTRODUCTION}

The Japanese Euphorbiaceae contains many toxic substances. However, when we initiated our studies ten years ago on the alkaloids of Daphniphyllum macropodum Miquel (Yuzuriha in Japanese) not much was known about these toxic constituents. The skeletons of these toxic alkaloids, which are all unique and so far have not been encountered in other species, can now be classified into five groups. The other constituents found in Euphorbiaceae are diterpenoids containing many oxygen atoms and these toxic diterpenoids structurally belong to three groups:

(a) An alkaloid linked to a polyoxygenated diterpene;

(b) Fatty acid ester of polyoxygenated diterpene (Professor Hecker and his co-workers also have studied these compounds, but the details of their work will be omitted from this lecture);

(c) Other polyoxygenated diterpenes.

These compounds are not only physiologically active but exhibit interesting physical and chemical properties. I will first discuss the structures and reactions of polyoxygenated natural products isolated from Euphorbia milli, Euphorbia jolkini, and Euphorbia kansui, and then compare their physical and chemical properties with those of other physiologically active polyoxygenated compounds which we have studied to date:

(i) Alkaloid containing polyoxygenated sesquiterpenes isolated from Euonymus (insecticidal);

(ii) Polyoxygenated sesquiterpene from Illicium anisatum L. (highly toxic);

(iii) Tetrodotoxin from puffer fish (highly toxic). 


\section{DAPHNIPHYLLUM ALKALOIDS}

\subsection{Introduction}

About three hundred genera, eight thousand species are known to belong to Euphorbiaceae. When we started our studies on the toxic constituents, Daphniphyllum was classified as Euphorbiaceae but its classification as a Daphniphyllaceae is now prevalent.

In Japan the following three species have been identified as belonging to Daphniphyllaceae:

(1) Daphniphyllum macropodum Miquel (widely distributed on the Pacific Ocean side);

(2) Daphniphyllum macropodum var. humile Maxim Rosenthal (distributed on the Japan Sea side);

(3) Daphniphyllum teijsmanni Zollinger (warm sea coasts).

These plants have been used traditionally in Japan as ornaments for New Year's day but their toxicities were also known to the populace. They exhibit vermicidal activity and also cause asthma. One of the main alkaloids, yuzurimine, causes slight paralysis of the central nervous system at low concentrations. At higher concentrations it has a sedative activity and also causes muscle relaxation. This activity is due to the various alkaloids which differ from species to species. The content also varies with the season, species, and source (i.e. leaves, fruit, etc).

The plant Daphniphyllaceae contains a great variety of related alkaloids. Twenty-six alkaloids have been isolated to date, as shown in Tables 1 and 2, which can be divided into the following five types depending on the nitrogen-

Table 1. Alkaloids from the bark and leaves

\begin{tabular}{|c|c|c|}
\hline Alkaloid & Formula & M.pt $\left({ }^{\circ} \mathrm{C}\right)$ \\
\hline $\begin{array}{l}\text { Daphniphylline } \\
\text { Codaphniphylline } \\
\text { Daphniphyllidine } \\
\text { Daphnimacropine } \dagger \\
\text { Daphmacrine } \dagger \\
\text { Daphmacropodine } \dagger \\
\text { Secodaphniphylline } \\
\text { Methyl homosecodaphniphyllate } \\
\text { Daphnilactone-A } \\
\text { Yuzurimine } \\
\text { Macrodaphnine } † \\
\text { Yuzurimine-A } \\
\text { Macrodaphniphyllamine } † \\
\text { Yuzurimine-B } \\
\text { Macrodaphniphyllidine } \dagger \\
\text { Yuzurimine-C } \\
\text { Neodaphniphylline* } \\
\text { Yuzurine } \\
\text { Alkaloid A }{ }^{*} \\
\text { Neoyuzurimine* } \\
\text { Yuzurimine-D* }\end{array}$ & $\begin{array}{l}\mathrm{C}_{32} \mathrm{H}_{49} \mathrm{O}_{5} \mathrm{~N} \\
\mathrm{C}_{33} \mathrm{H}_{47} \mathrm{O}_{3} \mathrm{~N} \\
\mathrm{C}_{30} \mathrm{H}_{47} \mathrm{O}_{4} \mathrm{~N} \\
\mathrm{C}_{30} \mathrm{H}_{47} \mathrm{O}_{4} \mathrm{~N} \\
\mathrm{C}_{32} \mathrm{H}_{49} \mathrm{O}_{4} \mathrm{~N} \\
\mathrm{C}_{32} \mathrm{H}_{51} \mathrm{O}_{4} \mathrm{~N} \\
\mathrm{C}_{33} \mathrm{H}_{47} \mathrm{O}_{3} \mathrm{~N} \\
\mathrm{C}_{23} \mathrm{H}_{37} \mathrm{O}_{2} \mathrm{~N} \\
\mathrm{C}_{23} \mathrm{H}_{35} \mathrm{O}_{2} \mathrm{~N} \\
\mathrm{C}_{27} \mathrm{H}_{37} \mathrm{O}_{7} \mathrm{~N} \\
\mathrm{C}_{27} \mathrm{H}_{39} \mathrm{O}_{7} \mathrm{~N} \\
\mathrm{C}_{25} \mathrm{H}_{35} \mathrm{O}_{5} \mathrm{~N} \\
\mathrm{C}_{23} \mathrm{H}_{33} \mathrm{O}_{4} \mathrm{~N} \\
\mathrm{C}_{23} \mathrm{H}_{33} \mathrm{O}_{3} \mathrm{~N} \\
\mathrm{C}_{25} \mathrm{H}_{35} \mathrm{O}_{4} \mathrm{~N} \\
\mathrm{C}_{23} \mathrm{H}_{29} \mathrm{O}_{5} \mathrm{~N} \\
\mathrm{C}_{24} \mathrm{H}_{37} \mathrm{O}_{4} \mathrm{~N} \\
\mathrm{C}_{23} \mathrm{H}_{33} \mathrm{O}_{3} \mathrm{~N} \\
\mathrm{C}_{24} \mathrm{H}_{31} \mathrm{O}_{5} \mathrm{~N}\end{array}$ & $\begin{array}{l}238-240(\mathrm{~B} . \mathrm{HCl}) \\
266-267(\mathrm{~B} . \mathrm{HCl}) \\
263-264 \text { (B.MeI) } \\
306-307 \text { (B.MeI) } \\
\quad>300 \text { (B.HBr) } \\
214 \\
129-130 \\
102.5-103 \\
194.5-195.5 \\
150-152 \\
180-181.5 \\
249-252 \text { (B.HCl) } \\
152-153 \\
282-284.5(\mathrm{~B} . \mathrm{HCl}) \\
305-306 \text { (B.HBr) } \\
186-187 \\
242-244 \text { (B.HCl) } \\
229-230 \text { (B.MeI) } \\
225-226 \text { (B. MeI) } \\
195-198 \text { (B.Picrate) } \\
194-195\end{array}$ \\
\hline
\end{tabular}

* Alkaloids of undetermined structure.

+ Isolated by Dr T. Nakano and his co-workers. 
Table 2. Alkaloids from the fruits

\begin{tabular}{|c|c|c|}
\hline Alkaloid & Formula & M.pt $\left({ }^{\circ} \mathrm{C}\right)$ \\
\hline $\begin{array}{l}\text { Daphniphylline } \\
\text { Methyl homodaphniphyllate } \\
\text { Daphniteijsmine } \\
\text { Methyl homosecodaphniphyllate } \\
\text { Daphnilactone-B } \\
\text { Yuzurimine } \\
\text { Yuzurimine-A } \\
\text { Yuzurimine-B } \\
\text { Daphnijsmine } \\
\text { Desacetyldaphnijsmine }\end{array}$ & $\begin{array}{l}\mathrm{C}_{32} \mathrm{H}_{49} \mathrm{O}_{5} \mathrm{~N} \\
\mathrm{C}_{23} \mathrm{H}_{37} \mathrm{O}_{2} \mathrm{~N} \\
\mathrm{C}_{32} \mathrm{H}_{49} \mathrm{O}_{5} \mathrm{~N} \\
\mathrm{C}_{23} \mathrm{H}_{37} \mathrm{O}_{2} \mathrm{~N} \\
\mathrm{C}_{22} \mathrm{H}_{31} \mathrm{O}_{2} \mathrm{~N} \\
\mathrm{C}_{27} \mathrm{H}_{37} \mathrm{O}_{7} \mathrm{~N} \\
\mathrm{C}_{25} \mathrm{H}_{35} \mathrm{O}_{5} \mathrm{~N} \\
\mathrm{C}_{23} \mathrm{H}_{33} \mathrm{O}_{3} \mathrm{~N} \\
\mathrm{C}_{25} \mathrm{H}_{33} \mathrm{C}_{5} \mathrm{~N} \\
\mathrm{C}_{23} \mathrm{H}_{31} \mathrm{O}_{4} \mathrm{~N}\end{array}$ & $\begin{array}{l}238-240(\mathrm{~B} . \mathrm{HCI}) \\
233-234(\mathrm{~B} . \mathrm{HCl}) \\
187-188 \\
102.5-103 \\
92-94 \\
150-152 \\
249-252(\mathrm{~B} . \mathrm{HCl}) \\
282-284.5(\mathrm{~B} . \mathrm{HCl}) \\
205-207 \\
\text { ca. } 200\end{array}$ \\
\hline
\end{tabular}

containing skeleton: (1) Daphniphylline, (2) Secodaphniphylline, (3) Daphnilactone-A, (4) Daphnilactone-B, and (5) Yuzurimine.

\subsection{Daphniphylline-type alkaloids}

The structures of seven of these are known, a representative member being daphniphylline (1), the structure of which was unambiguously elucidated by means of an $\mathrm{x}$-ray crystallographic analysis ${ }^{1}$. The main difference is seen in the non-nitrogen containing portion. The mass spectra of these alkaloids have a pair of prominent peaks at $m / e 286$ and 272 which have played an important role in the structural determination. As shown below, the first

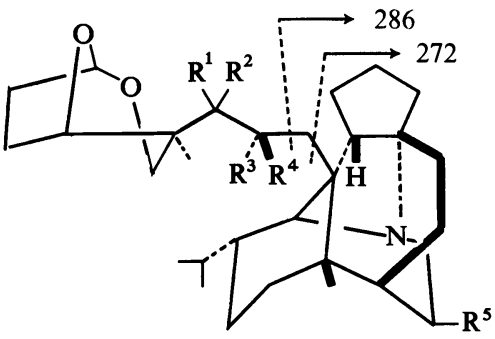

Daphniphylline (1) $\stackrel{\mathrm{R}^{1}}{\backslash}=\mathrm{O}, \mathrm{R}^{3}=\mathrm{OAc}, \mathrm{R}^{4}=\mathrm{R}^{5}=\mathrm{H}$

Codaphniphylline (2) $\underset{R^{2}}{R^{1}}=\mathrm{O}, \mathrm{R}^{3}=\mathrm{R}^{4}=\mathrm{R}^{5}=\mathrm{H}$

Daphniphyllidine (3) $\mathrm{R}^{1}=\mathrm{OH}, \mathrm{R}^{2}=\mathrm{R}^{5}=\mathrm{H}, \underset{\mathrm{R}^{4}}{\mathrm{R}^{3}}=\mathrm{O}$ Daphnimacropine (4) ${ }_{\mathrm{R}^{2}}^{*}=\mathrm{O}, \mathrm{R}^{3}=\mathrm{R}^{4}=\mathrm{H}, \mathrm{R}^{5}=\mathrm{OH}$

Daphmacrine (5)

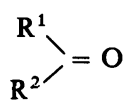

Daphmacropodine (6) $\mathrm{R}^{1}=\mathrm{OH}, \mathrm{R}^{2}=\mathrm{H}$

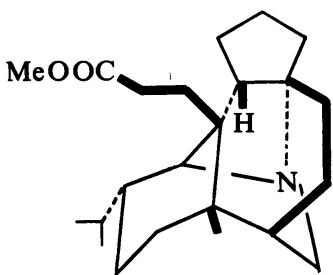

Methyl homodaphniphyllate (7)

* Private communication from Dr K. Osaki (Kyoto University): a tentative structure (4) has been allotted to daphnimacropine. 
four alkaloids $\left(\mathbf{1}^{1}, \mathbf{2}^{2}, 3^{3}\right.$ and 4) all have the same ketal moiety. Daphmacrine $(5)^{4}$ and daphmacropodine (6) ${ }^{5}$ were both isolated by Dr Nakano and his co-workers. Biogenetically, they are quite interesting. Methyl homodaphniphyllate (7) is one of the significant $\mathbf{C}_{22}$-alkaloids ${ }^{6}$, which has been derived from daphniphylline (1) in several steps, as shown below. Some reactions of

\section{Chemical Transformation from Daphniphylline to Methyl homodaphniphyllate}

$\begin{array}{lll}\text { Daphniphylline (1) } & \stackrel{\text { (1) } \mathrm{OH}^{-}}{\longrightarrow} & \begin{array}{l}\text { (4) } p-\mathrm{TsCl}-\mathrm{Py} \\ \text { (2) } \mathrm{NaIO}_{4}\end{array} \\ \begin{array}{ll}\text { (3) } \mathrm{NaBH}_{4} & \text { (5) } \mathrm{NaCN} \\ \text { (6) } 6 \mathrm{~N} \mathrm{HCl}\end{array} \\ \begin{array}{ll}\text { (7) } 20 \% \mathrm{HCl}-\mathrm{MeOH}\end{array}\end{array}$

the ketal moiety have been carried out in order to clarify some biogenetic and structural points. During the course of these studies a modified Clemmensen reduction has been found and applied to keto steroids ${ }^{7}, \alpha-\beta$-unsaturated ketones and $\beta$-diketones ${ }^{8}$. In addition, chemical reactions on the nitrogen<smiles>[R]C1OC([AlH2])C(C)(C)C1=O</smiles>

(2) $\mathrm{Ac}_{2} \mathrm{O}-\mathrm{Py}$

$\mid \begin{aligned} & \mathrm{Zn} \text { in } \mathrm{Ac}_{2} \mathrm{O}-\mathrm{Py} \\ & 0^{\circ}, 2 \mathrm{~h}\end{aligned}$

$\mid \begin{aligned} & \mathrm{Zn} \text { in } \mathrm{Ac}_{2} \mathrm{O}-\mathrm{Py} \\ & 0^{\circ}, 2 \mathrm{~h}\end{aligned}$

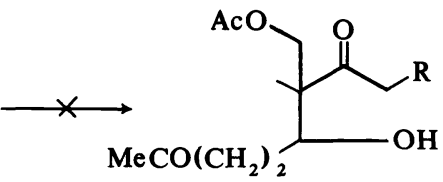<smiles>[R]C1OC([R18])C(C)(COC(C)=O)C1=O</smiles>

heterocyclic skeleton of the daphniphylline-type compounds have also been carried out. A new nitrogen-containing skeleton was constructed from daphniphylline (1), as shown below ${ }^{9}$. 
(1)
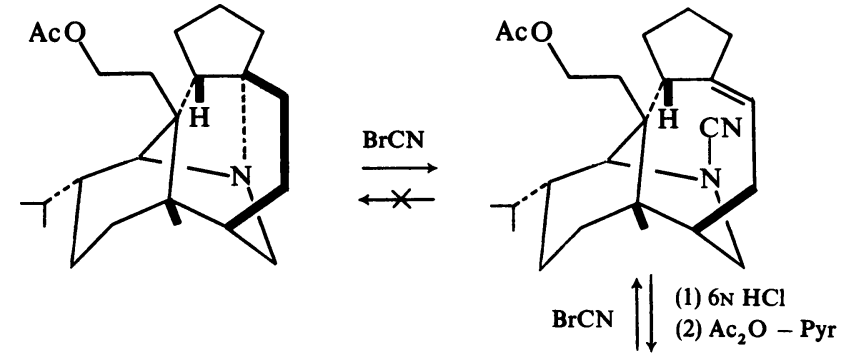

\subsection{Secodaphniphylline-type alkaloids}

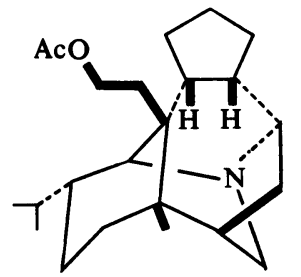

The structures of two alkaloids [secodaphniphylline (8) and methyl homosecodaphniphyllate (9)] have been elucidated ${ }^{10}$. Quite recently, another new alkaloid, daphniteijsmine (10), was isolated from the fruit ${ }^{11}$.

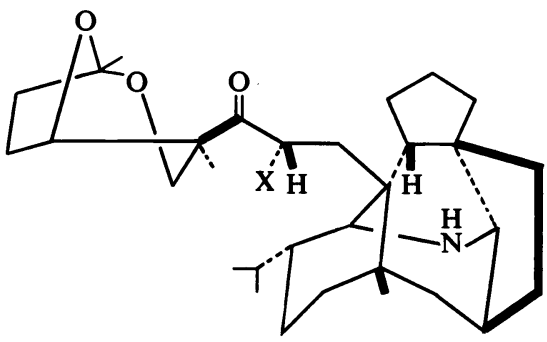

(8) $\mathrm{X}=\mathrm{H}$

(10) $X=O A c$

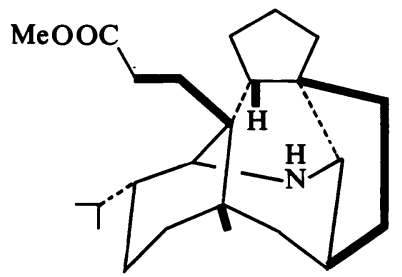

(9)

Biogenetically, secodaphniphylline can be regarded as an important precursor of the other daphniphyllum alkaloids. Furthermore, from a structural viewpoint, oxidation of the alkaloid (9) with $\mathrm{Pb}(\mathrm{OAc})_{4}$ is of interest ${ }^{12}$, since this leads to the formation of a stable anti-Bredt's rule imine. Since then, the following non-isolatable anti-Bredt's rule imines have been reported as unstable reaction intermediates ${ }^{13,14}$.

Formation of an anti-Bredt's rule imine

(9)

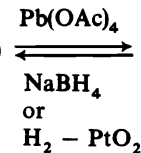

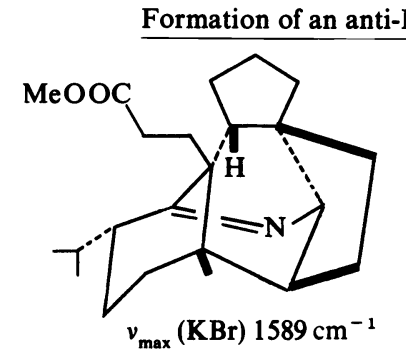

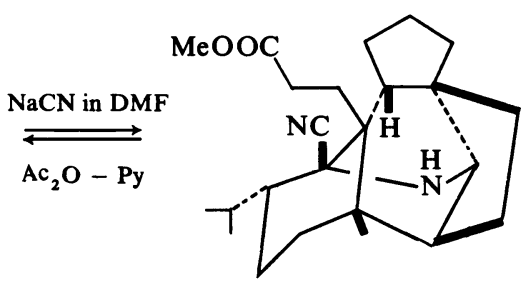



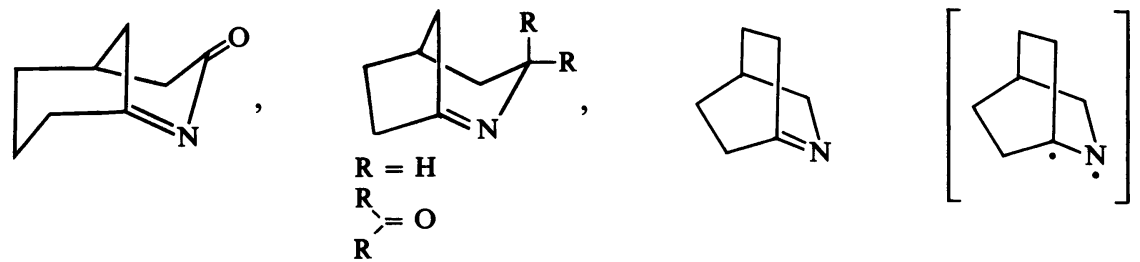

\subsection{Daphnilactone-A}

The carbon skeleton of daphnilactone-A (11) consists of twenty-three carbon atoms. Biogenetically, this alkaloid is derived from a squalene-like intermediate through a possible precursor (12), which has not yet been isolated but must be present in the plant ${ }^{10,15}$.
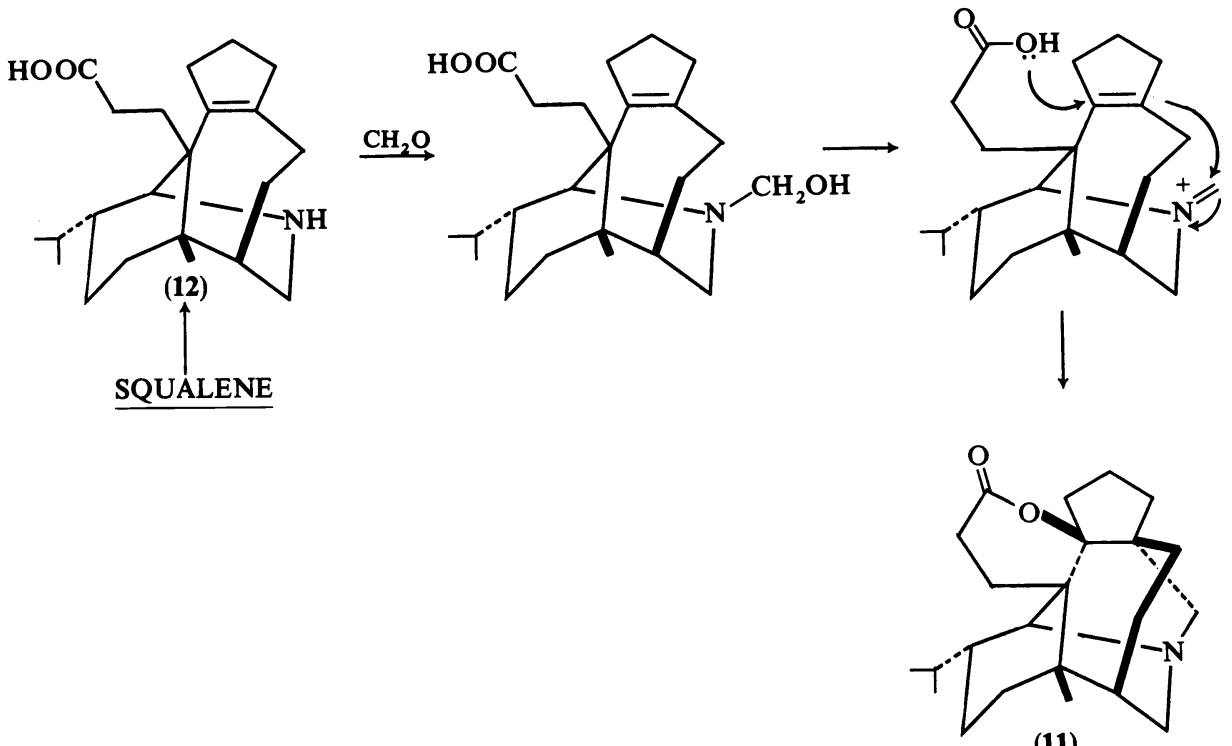

(11)

\subsection{Daphnilactone-B}

Daphnilactone-B (13) is a main alkaloid isolated from the fruit of the plant Daphniphyllum teijsmanni Zollinger ${ }^{6,16}$. Biogenetically, this alkaloid is a plausible intermediate between the two main groups represented by daphniphylline and yuzurimine. As shown below, daphnilactone-B was converted into the daphniphylline-type compound (14) through a secondary amine as an intermediate. 
TOXIC SUBSTANCES OF EUPHORBIACEAE

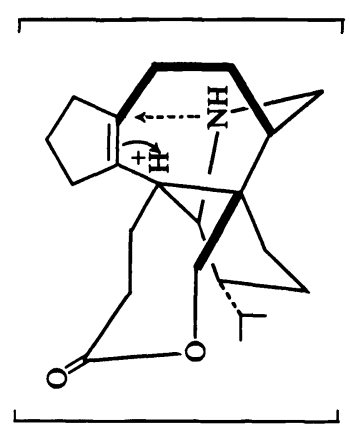

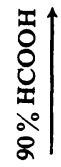
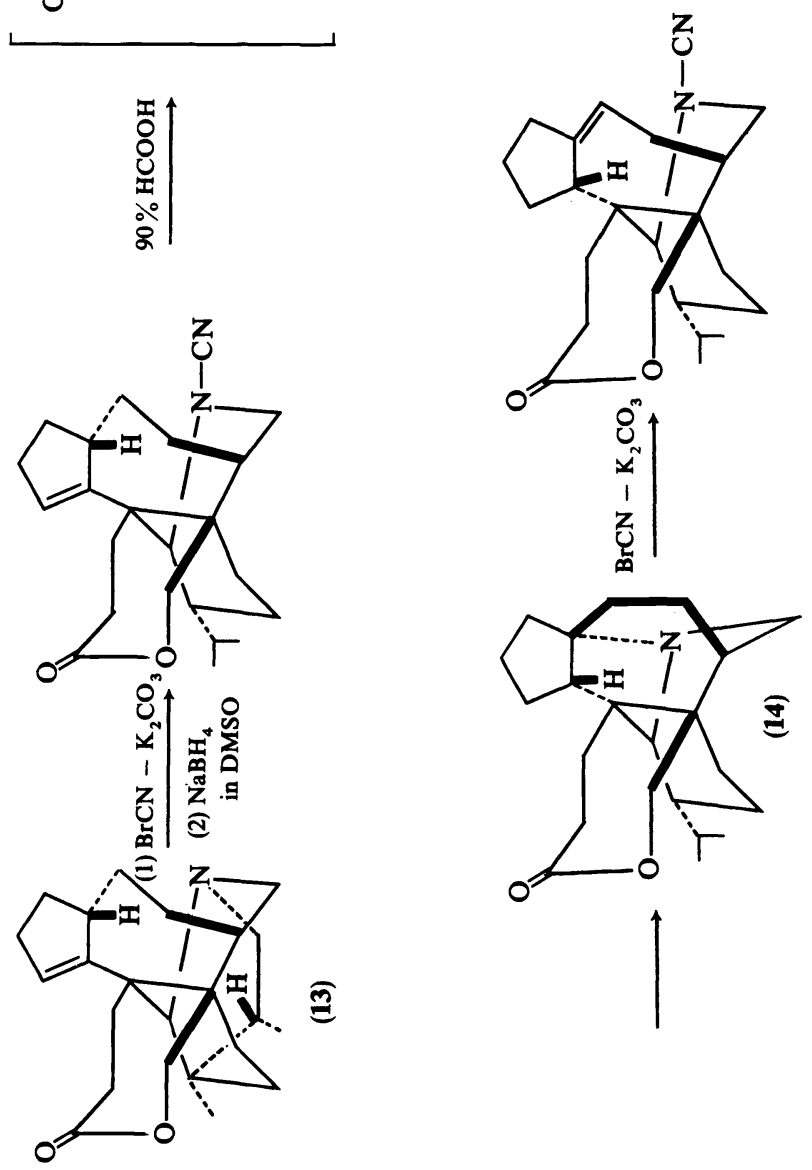


\subsection{Yuzurimine-type alkaloids}

The structures of ten of these are known as represented by yuzurimine $(15)^{17}$. Among them, three alkaloids $\left(21^{18}, 2^{19}\right.$ and $\left.23^{19}\right)$ have an interesting $\mathrm{N}$-oxide structure, which can be characterized by their mass spectra showing three fragment peaks $\left[\mathrm{M}^{+}-16, \mathrm{M}^{+}-17\right.$, and $\left.\mathrm{M}^{+}-18\right]$. On the other hand, yuzurine (24) is different from the others in the $N$-heterocyclic skeleton ${ }^{20}$. Biogenetically, however, this alkaloid may be derived from yuzurimine-B (18).

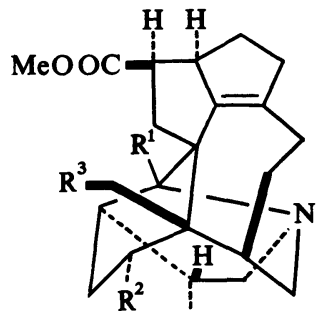

Yuzurimine (15) $\mathbf{R}^{1}=\mathrm{OH}, \mathbf{R}^{2}=\mathrm{R}^{3}=\mathrm{OAc}$

Yuzurimine-A (16) ${ }^{17,21} R^{1}=O H, R^{2}=O A c, R^{3}=H$

Macrodaphniphyllame (17) $)^{22} R^{1}=R^{2}=O H, R^{3}=H$

Yuzurimine-B $(18)^{17,21} R^{1}=R^{2}=H, R^{3}=O H$

Macrodaphniphyllidine (19) ${ }^{22} R^{1}=R^{2}=H, R^{3}=$ OAc

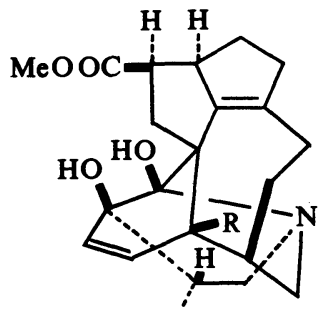

Yuzurimine-C (20) $)^{23}$

$\mathbf{R}=\mathbf{C H O}$

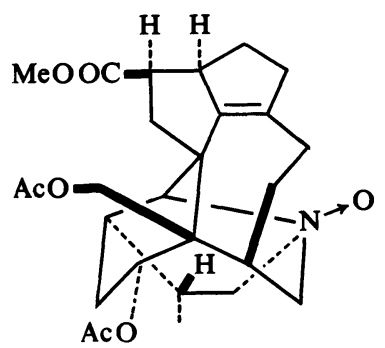

Macrodaphnine (21)

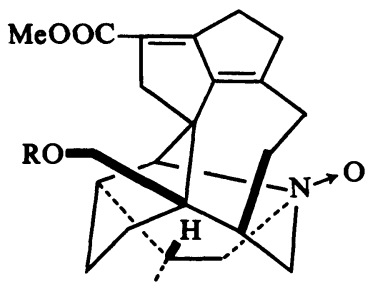

Daphnijsmine (22) $R=A c$

Desacetyldaphnujsmine (23) $R=H$

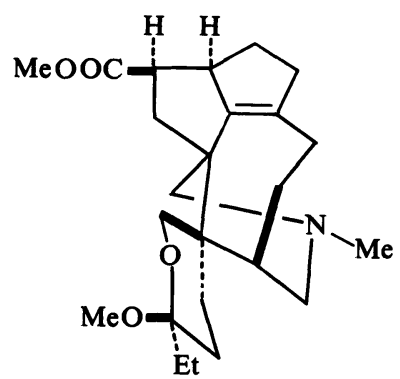

Yuzurine (24)

\subsection{Structural relationship}

The plant Daphniphyllaceae contains a great variety of related alkaloids. They are formally related to one another by bond formation or fission. The structural relationships of these alkaloids are shown in Scheme 1, which takes into consideration some biosynthetic experiments. 
TOXIC SUBSTANCES OF EUPHORBIACEAE

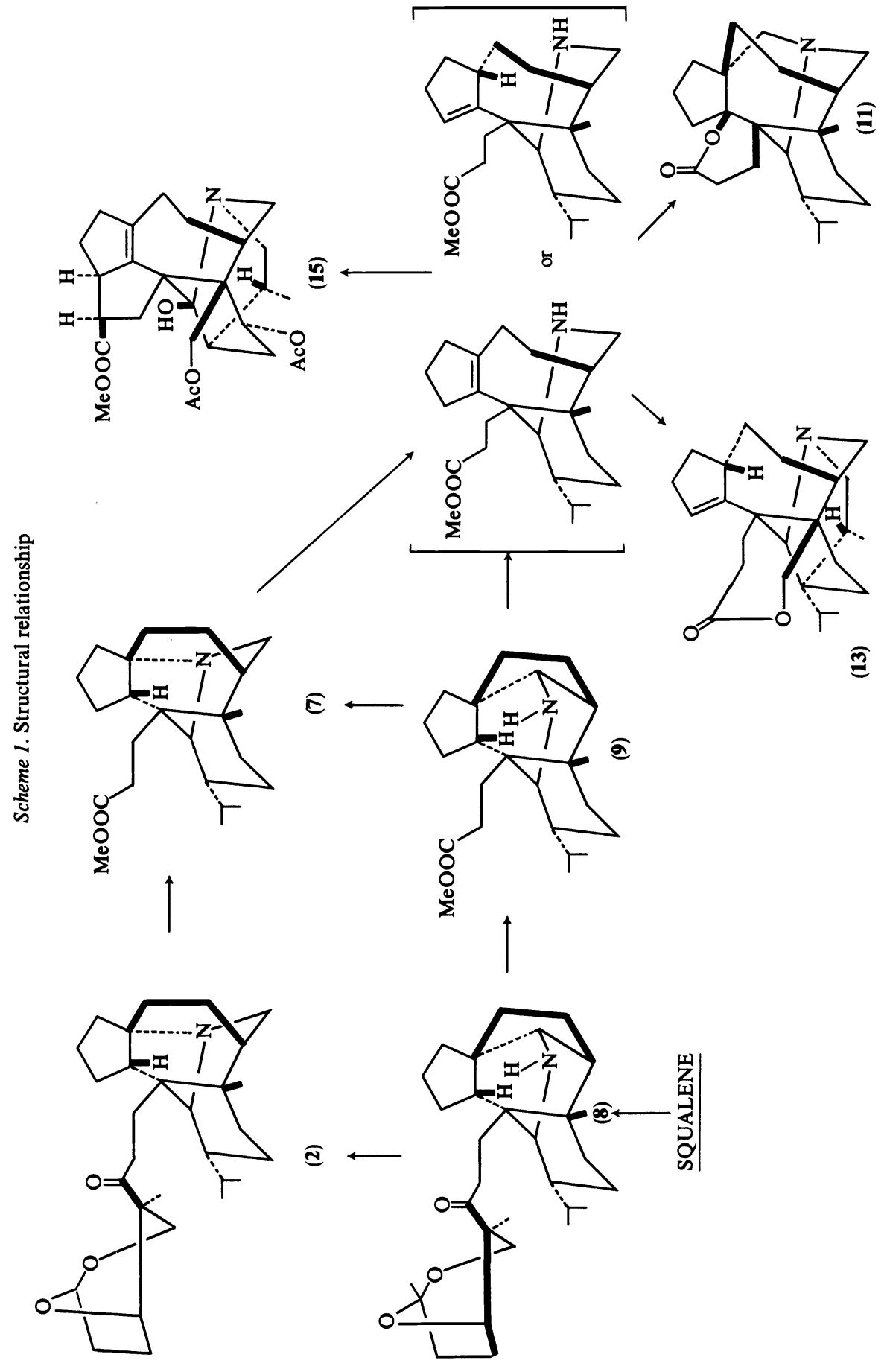




\subsection{Biosynthesis ${ }^{24}$}

Radioactive tracer experiments using $\left[2-{ }^{14} \mathrm{C}\right],\left[5-{ }^{14} \mathrm{C}\right]$ and $\left[4-{ }^{3} \mathrm{H}\right.$, $\left.2-{ }^{14} \mathrm{C}\right] \mathrm{MVA}$ and ${ }^{14} \mathrm{C}$-labelled squalene, prepared enzymatically from $\left[2-{ }^{14} \mathrm{C}\right] \mathrm{MVA}$, revealed that daphniphylline (1) and codaphniphylline (2) were biosynthesized from six molecules of MVA via a squalene-like intermediate. One of the main alkaloids, yuzurimine (15), did not incorporate MVA. Hence, it is presumably biosynthesized at a much later stage. From these biosynthetic studies coupled with stereostructures of the daphniphyllum alkaloids [daphniphylline (1), daphmacrine (5), and secodaphniphylline (8)], they are built up from a squalene-like intermediate, as shown in Schemes 2 and 3.

Scheme 2. A plausible pathway from squalene to daphniphylline

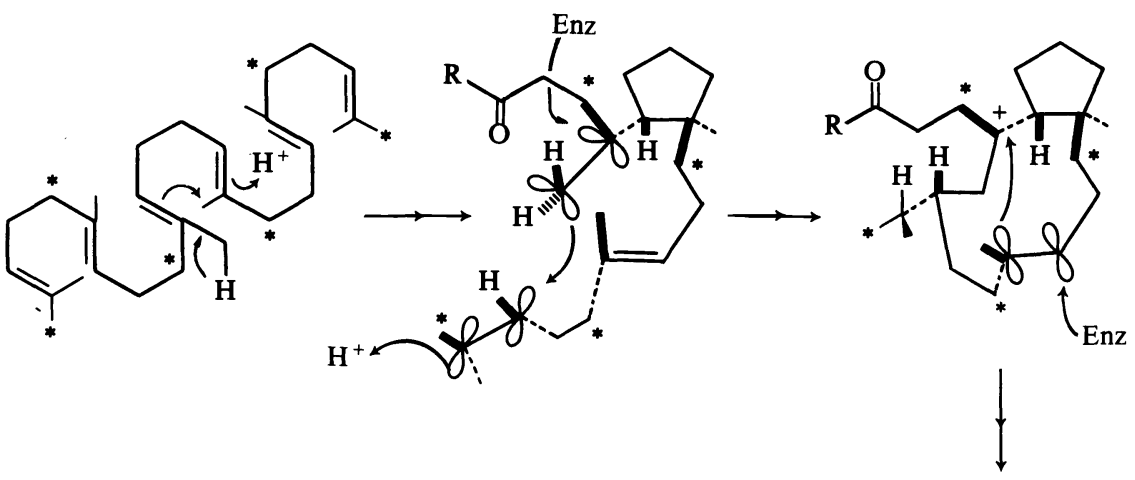

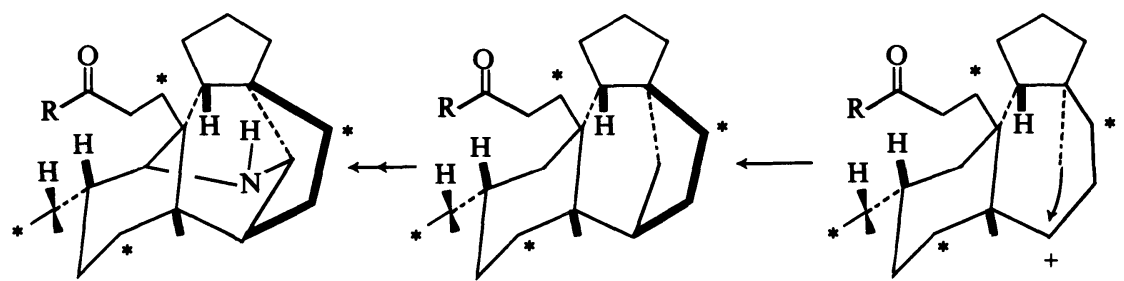

(8)

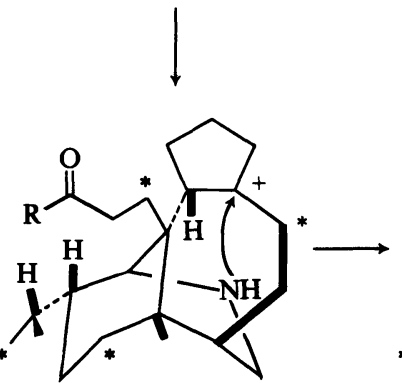

R: Ketal moiety

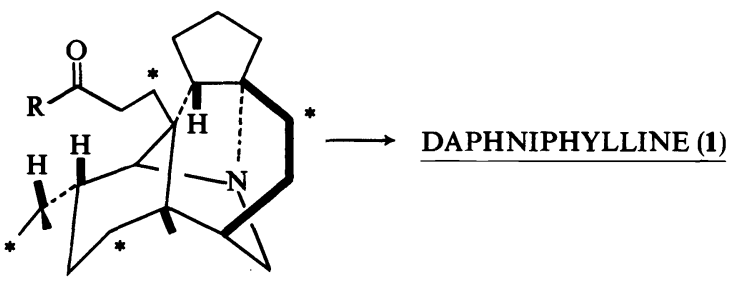

(2) 
Scheme 3. A plausible pathway from squalene-2,3-oxide to daphniphylline and daphmacrine

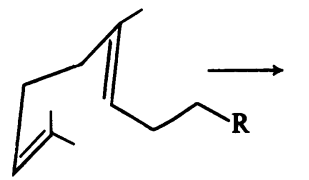

Squalene

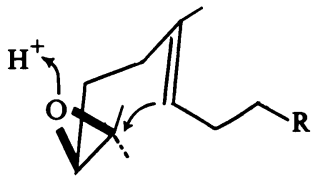

Squalene 2,3-oxide
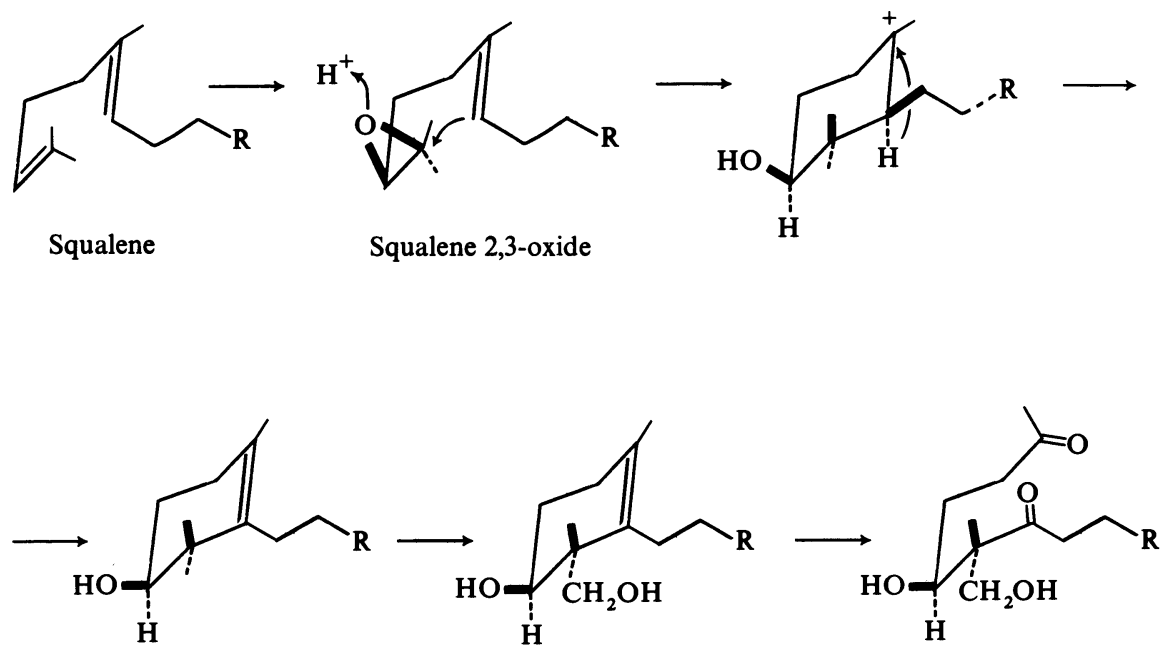

A common intermediate

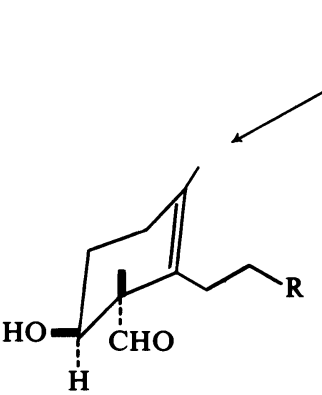

$\uparrow \uparrow$

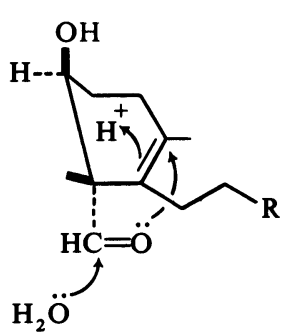

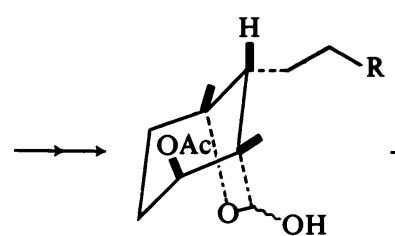

(6)

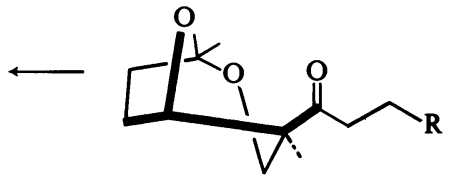

(2)
(1)

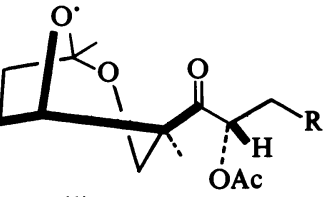

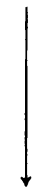

R: Amine moiety

or polyene 


\section{EUPHORBIA MILLII CH. DES MOULINS}

We will next discuss the toxic root constituents of Euphorbia millii Ch. des Moulins. Although these plants are widely cultivated for decorative purposes, their toxicity was also known. Three toxic constituents, milliamines $\mathbf{A}(25)$, $\mathbf{B}(26)^{25}$, and $\mathbf{C}(27)^{26}$ had been isolated and structurally elucidated. The skeleton is the diterpene ingenol ${ }^{27}$ to which Dragendorff-positive nitrogen containing compounds are attached through an ester linkage. The Dragendorff-positive moieties are anthranilic acid, 3-hydroxyanthranilic acid, and $\mathrm{N}, \mathrm{N}$-dimethylanthranilic acid. The carcinogenic activity of these highly toxic compounds is under investigation. In addition, compound (28) has also been isolated from this plant. This compound is non-crystalline and the molecular formula was established by the field desorption mass spectrum ${ }^{28}$.

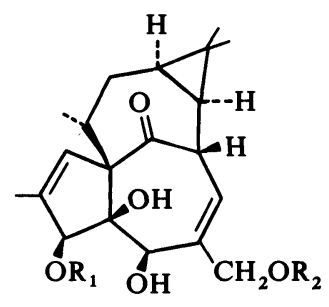

(25) $R_{1}=X, R_{2}=A c$

(26) $R_{1}=H, R_{2}=X$

(27) $R_{1}=X, R_{2}=H$<smiles>[X]C(=O)c1ccccc1NC(=O)c1cccc(O)c1NC(=O)c1ccccc1N(C)C</smiles>

(28) $\mathrm{C}_{20} \mathrm{H}_{27} \mathrm{O}_{6}-\mathrm{Y}$

\section{EUPHORBIA JOLKINI BOISS}

The title plant is perennial which is found among rocks on the warmer coasts of Japan. From its roots we have characterized ingenol esterified at 3-OH with 2,4,6,8,10-tetradecapentaenoic $\mathrm{acid}^{26}$. The following reaction was encountered during the process of determining the site of esterification.

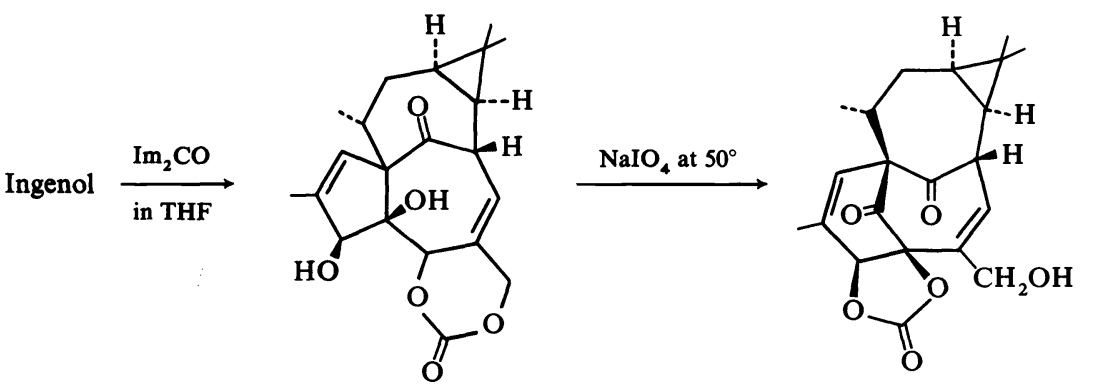

Furthermore, biogenetically related compounds with an ingenol or phorbol $^{29}$ system, named jolkinol ${ }^{30}-\mathrm{A}(29),-\mathrm{B}(30)$, and $-\mathrm{C}(31)$, were isolated and their structures have been also determined. 
Five jolkinolides ${ }^{31,32}$ possessing the abietane skeleton, were also isolated from this plant. Jolkinolide $\mathrm{B}(\mathbf{3 3})$ has novel functional groups, some interesting reactions of which are depicted below.

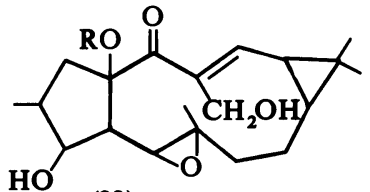

(29)

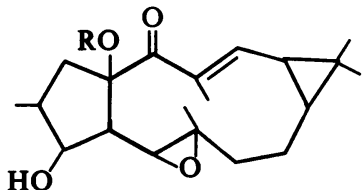

(30)

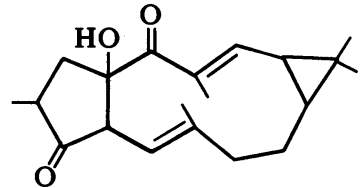

(31)

$\mathbf{R}=$ cinnamoyl

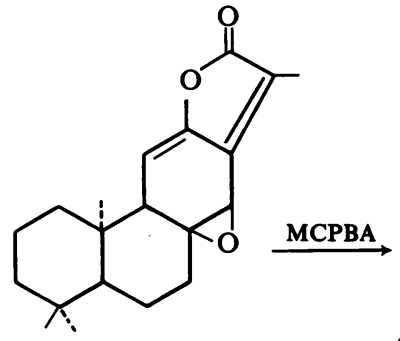

(32) Jol A<smiles>CC1=C2CC3(O)CCC4C(C)(C)CCC[C@]4(C)C3C(O)C2OC1=O</smiles>

(37)

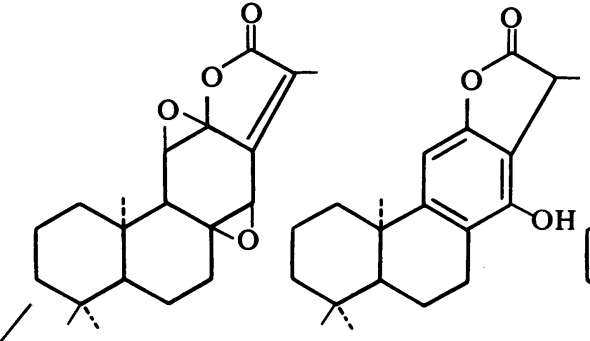

(34) $\mathrm{C}$<smiles>C=C1C(=O)OC2CC3C(=CC12O)CCC1C(C)(C)CCCC31C</smiles>

(35) $\mathrm{D}$

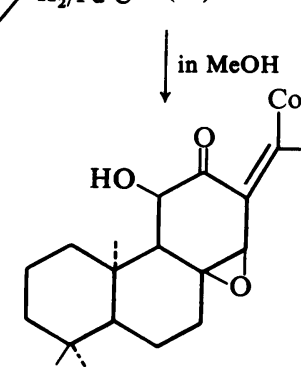

(38)<smiles>Cl[Ga]C1CCC1</smiles><smiles>CC1C(=O)Oc2cc3c(cc21)CCC1C(C)(C)CCCC31C</smiles>

(39)<smiles>CC1=C2C=C3CCC4C(C)(C)CCCC4(C)C3CC2OC1=O</smiles>

(36) $\mathrm{E}$

\section{EUPHORBIA KANSUI LIOU}

The toxicity of the Chinese herb 'Kansui' has been known for a long time. In spite of its pharmacological utility it is difficult for a herb doctor to determine the optimum dose. A study of the toxic principles resulted in the isolation of ingenol and 13-oxyingenol derivatives ${ }^{33,34}\left(\mathrm{LD}_{50} 0.75 \mathrm{mg} / \mathrm{kg}\right.$ and $1.0 \mathrm{mg} / \mathrm{kg}$, respectively) as the main toxic components. Moreover, toxic and analgesic compounds, Kansuinines $A$ and $B^{35}$ have been isolated. In fact, kansuinine A shows that the analgesic and anti-writhing (Phenyl-quinone writhing) activity is $0.5 \mathrm{mg} / \mathrm{kg}$ and the toxicity is $30 \mathrm{mg} / \mathrm{kg}$ for mice.

\subsection{Isolation}

The procedure for the isolation is shown in Figure 1. Commercially available 'Kansui' was extracted with ethanol for one week, and the ethanol 


\section{YOSHIMASA HIRATA}

extracts were concentrated under reduced pressure. The resulting syrup (ca. $1 \mathrm{~kg}$ ) was extracted with benzene many times. The combined benzene layers were concentrated in vacuo. The oily material was separated by column chromatography (silicic acid). The portion eluted by methanolchloroform (v/v: 2/98) afforded toxic fractions $\left(2 \mathrm{~g}, \mathrm{LD}_{50} 2 \mathrm{mg} / \mathrm{kg}\right)$. The components were separated by preparative thin-layer chromatography with the use of methanol-chloroform (v/v: 3/33) as solvent. At this stage, kansuinine $A$ was crystallized from ether and petroleum ether, whereas kansuinine B could not be purified completely by thin-layer chromatography; the purification was achieved by high pressure liquid chromatography with gradient elution (MicroPak column, $1 \mathrm{~m}^{36}$ ), affording pure kansuinine $\mathbf{B}$. The ingenol and 13-oxyingenol derivatives were also separated by the same procedure as described above.

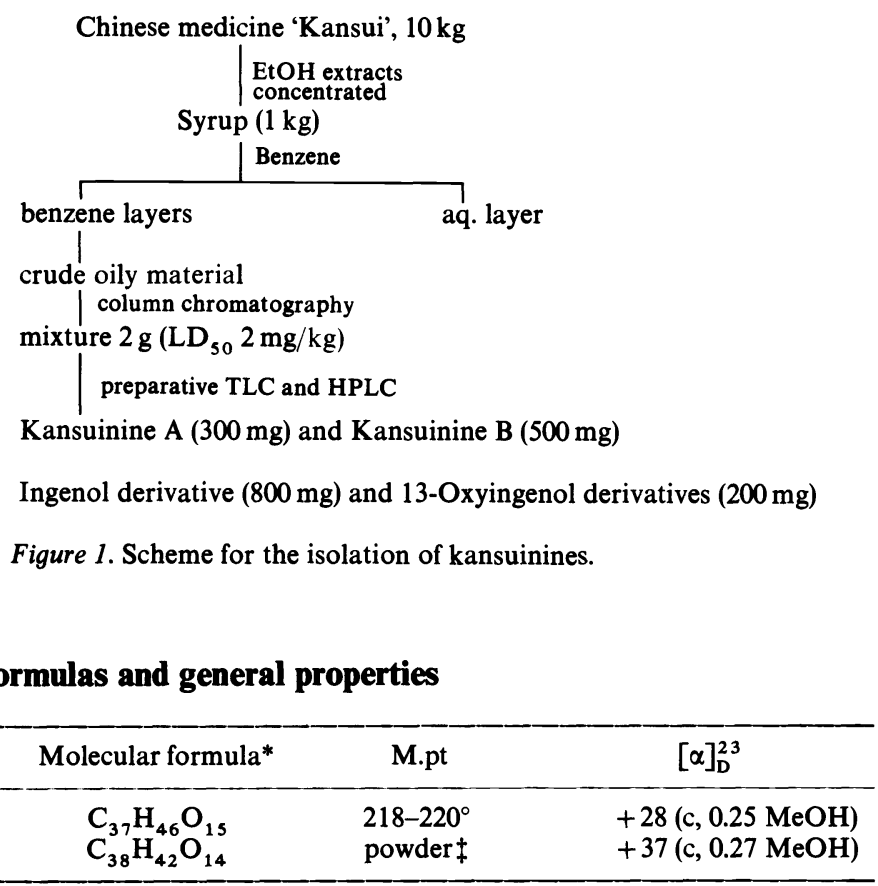

\subsection{Molecular formulas and general properties}

\begin{tabular}{lccc} 
& Molecular formula* & M.pt & {$[\alpha]_{\mathrm{D}}^{23}$} \\
\hline Kansuinine A & $\mathrm{C}_{37} \mathrm{H}_{46} \mathrm{O}_{15}$ & $218-220^{\circ}$ & $+28(\mathrm{c}, 0.25 \mathrm{MeOH})$ \\
Kansuinine B $\dagger$ & $\mathrm{C}_{38} \mathrm{H}_{42} \mathrm{O}_{14}$ & powder $\ddagger$ & $+37(\mathrm{c}, 0.27 \mathrm{MeOH})$ \\
\hline
\end{tabular}

* Secured by high resolution mass spectra.

+ Obtained as powder by the addition of petroleum ether to the ethereal solution of kansuinine B, purified by the above chromatographic procedures.

¥ Further purification by recyclic operation of HPLC afforded crystals of Kansuinine B, m.pt $160-162^{\circ}$.

\subsection{Structure of kansuinine A (40)}

The n.m.r. spectrum of kansuinine $\mathrm{A}$ is shown in Figure 2, which indicates that this compound has five acetate and one benzoate groups. This observation suggested that the parent alcohol is $\mathrm{C}_{20} \mathrm{H}_{32} \mathrm{O}_{9}$, a highly oxygenated diterpene. 


\subsubsection{Functional groups}

(a) Exocyclic methylene-Kansuinine A afforded a diol (41) by treatment with osmium tetroxide in pyridine followed by the addition of sodium bisulphite. In the n.m.r. spectrum of compound (41) two protons assigned to $\mathrm{CH}_{2} \mathrm{OH}$ appear as an $\mathrm{AB}$ quartet centred at $\delta 3.40$. Furthermore, this compound was converted to compounds (42) and (43).

(b) Tertiary alcohol-The acetylation of kansuinine A by the ordinary method (acetic anhydride-pyridine) did not proceed, but this compound gave a monomethyl ether (44) with silver oxide and methyl iodide in dimethylformamide, in which no more alcohol groups were present.

(c) Ketone-Kansuinine A was converted to compound (45) by reduction with sodium borohydride in tetrahydrofuran, from which kansuinine A was regenerated by oxidation with chromium trioxide in pyridine.

(d) Tertiary acetoxy group-Hydrolysis of compound (45) afforded compound (46), whose n.m.r. spectrum showed the absence of low field proton signals originally present in (45) except for those due to two protons assigned to exocyclic methylene.

These data showed that the properties of nine oxygens present in kansuinine - A are characterized as seven hydroxyls, one ketone, and one ethereal function. Consequently, the number of the ring system is three, including the ether ring. As shown in Figure 2, the values of coupling constants among the protons are small, so we tried to obtain derivatives better suited for structure elucidation by n.m.r. spectral analysis.

\subsubsection{Transannular ether formation}

The treatment of kansuinine A with p-toluenesulphonic acid afforded the deacetoxy compound (47) in good yield. The n.m.r. spectrum of this compound (47) is shown in Figure 3; the assignment of each proton was clearly made on this compound (47) by decoupling procedures and the observation of INDOR spectra. Furthermore, hydrogenation of compound (47) afforded a dihydro compound (48) with $\mathrm{Pd}-\mathrm{C}$ as catalyst. Based on the n.m.r. spectral data of compounds (47) and (48), it was possible to derive partial structures (I, II and III). The reduction of compound (47) with sodium borohydride gave compound (49). The findings that in the n.m.r. spectrum of compound (49) the signal of the new proton appeared at $\delta 3.65$ as a quartet $(J=4,6 \mathrm{~Hz})$, and the presence of a $\beta$-diketone system in compound (47), [proved by the formation of compounds (50) and (51)] suggested another partial structure (IV).

(I)

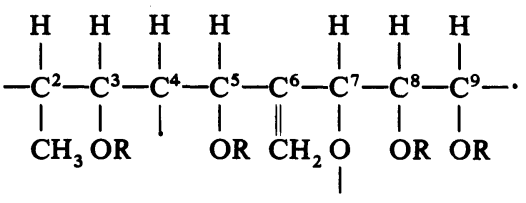

(II)<smiles>CCOC(=O)OCc1ccccc1</smiles>

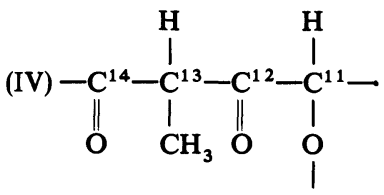


These partial structures (I, II, III, IV), coupled with biogenetic considerations suggested the structure of kansuinine $A$ as depicted in (40).

\subsubsection{The formation of eleven-membered lactone by a novel retro-aldol reaction}

Kansuinine A yielded lactone (52) with sodium hydride in tetrahydrofuran at $50^{\circ}$ for 30 minutes. The presence of protons due to the ethyl keto group and the proton on the carbon attached to the lactone oxygen were shown in the n.m.r. spectrum of compound (52). Lactone (52) was converted to methyl esters (53), which gave compound (54) on oxidation with periodic acid in acetone-water, the structure of which was fully established by spectral data. Compound (54) contains eleven carbon atoms of the parent diterpene skeleton.

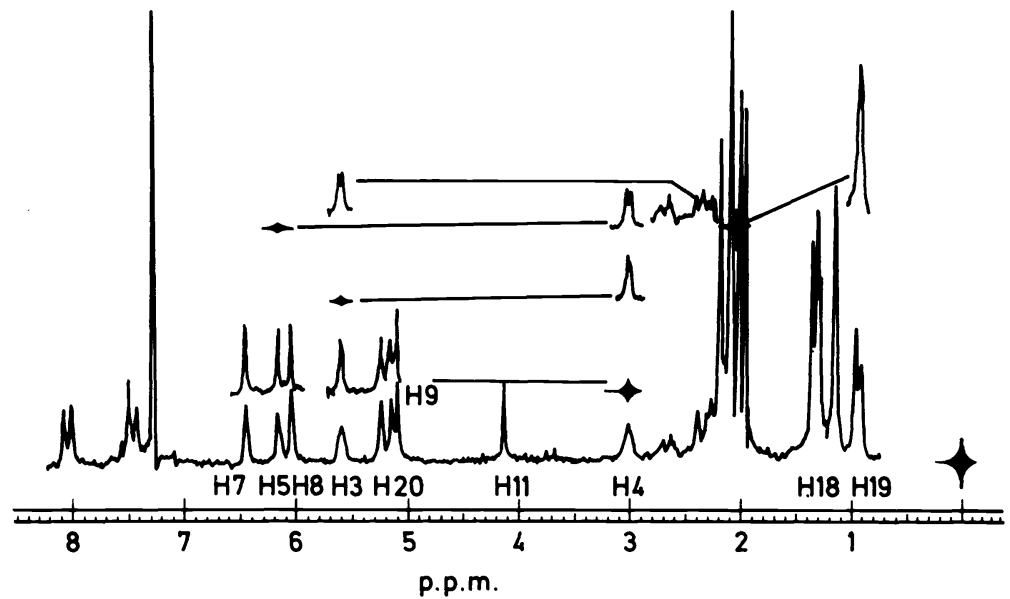

Figure 2. NMR spectrum (100 $\left.\mathrm{MHz}, \mathrm{CDCl}_{3}\right)$ of kansuinine A.

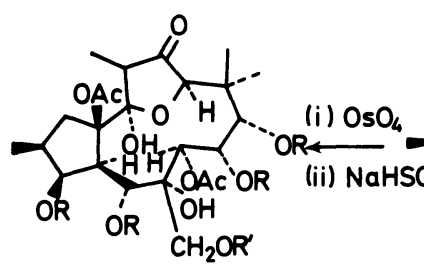

(41) $\mathrm{R}^{\prime}=\mathrm{H}$

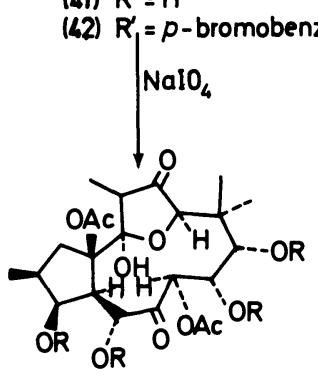

(43)

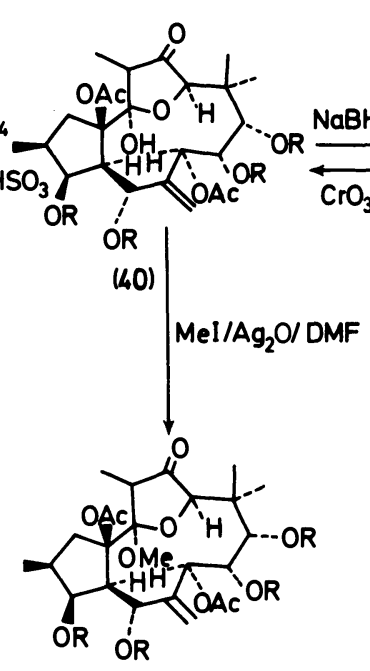

(164)

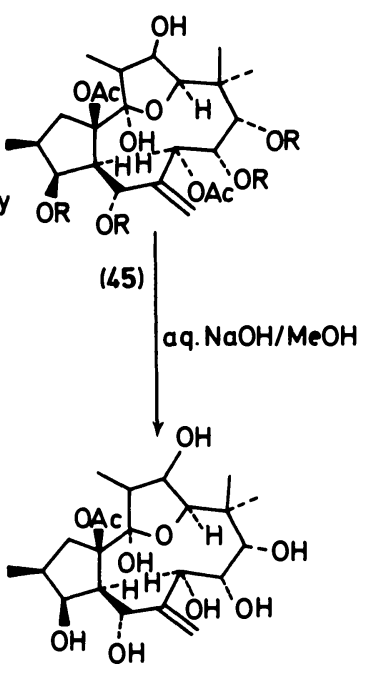

(46) 


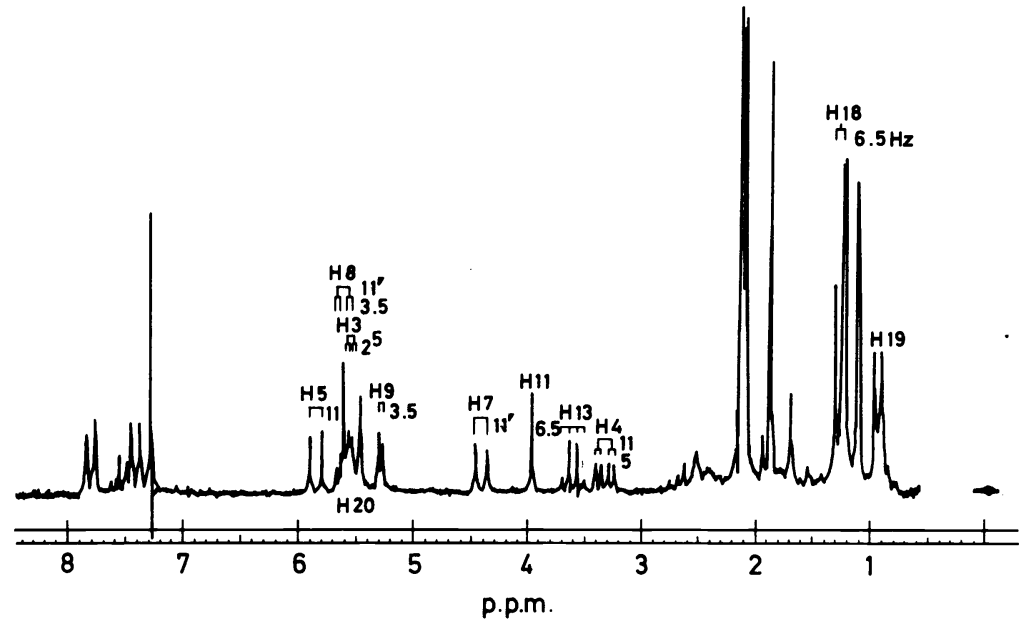

Figure 3. The NMR spectrum (100 MHz, $\left.\mathrm{CDCl}_{3}\right)$ of compound (47).

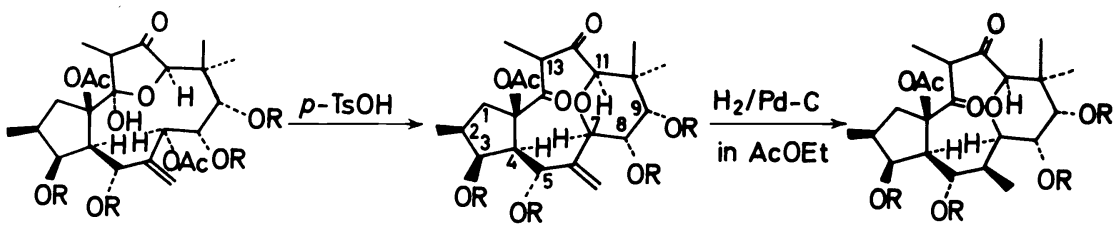

(40)

(47)

(48)

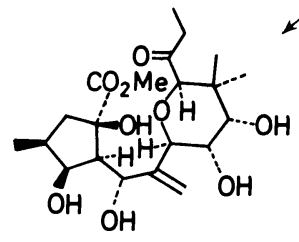

(50)

aq. $\mathrm{NaOH} / \mathrm{MeOH} \mathrm{NaBH}_{4}$ in THF

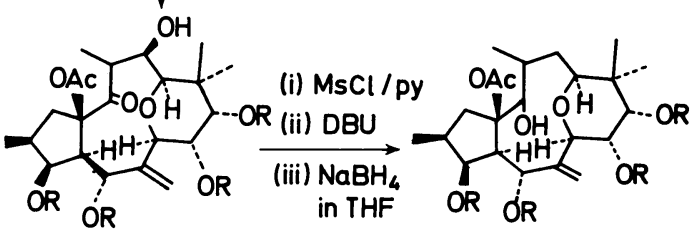

(49)

(51)
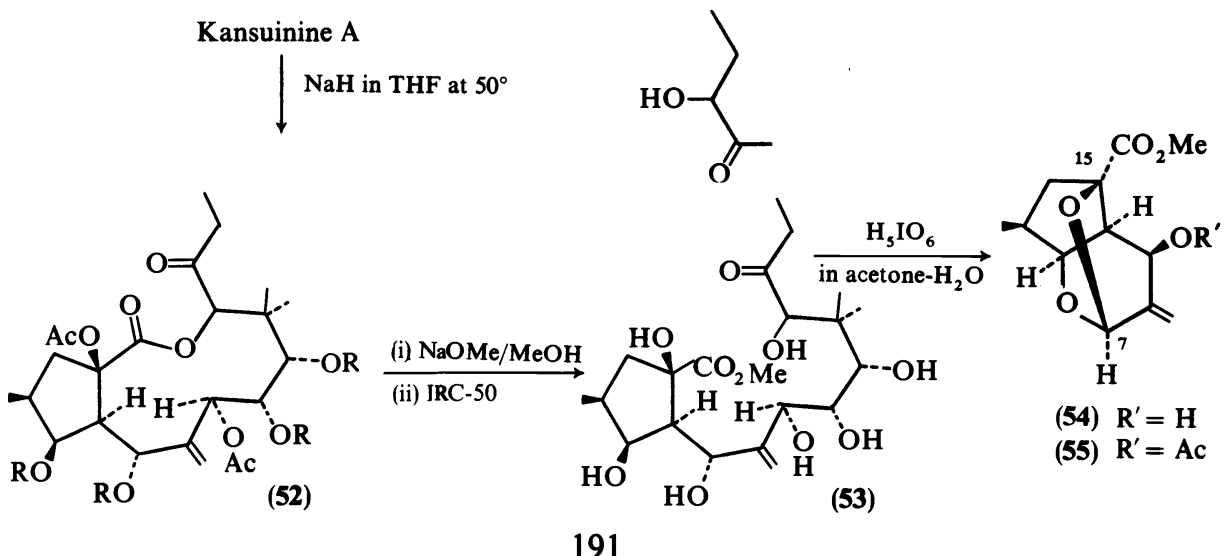

(54) $R^{\prime}=H$

(55) $R^{\prime}=A c$ 


\subsubsection{Stereochemistry of kansuinine $A$}

(a) Stereochemistry of compound (54)-Compound (54) was converted to the mono acetate (55), the n.m.r. spectrum of which gave the following stereochemical information. The three coupling constants, $J_{2,3}, J_{3_{1},}$, and $J_{4,5}$, are all $3 \mathrm{~Hz}$, suggesting an all-cis relationship. The stereochemistry at $\mathrm{C}-7$ and C-15 was necessarily determined as shown on steric grounds.

(b) Stereochemistry of compound (47)-Substituents attached at C-7, C-8, and $\mathrm{C}-9$ in the six-membered ether ring were trans and cis from consideration of the fact that two coupling constants, $J_{7,8}$ and $J_{8,9}$ are $11 \mathrm{~Hz}$ and $3.5 \mathrm{~Hz}$, respectively, and that compound (50) is reacted with one molar equivalent of sodium metaperiodate. In the NOE experiment of compound (47), a ten per cent increase of intensity of H-7 signal upon irradiation of $\mathrm{H}-4$ signal shows protons at C-7, C- 8 and C- 9 to have $\alpha, \beta$ and $\beta$ configurations, respectively. Furthermore, the observation of an NOE between H-7 and H-11 suggested the stereochemistry shown below for the structure of compound (47) except for $18-\mathrm{CH}_{3}$.

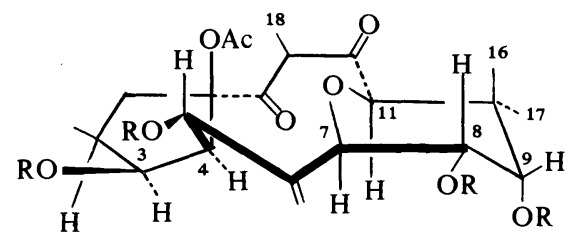

(c) Stereochemistry of kansuinine A-NOE experiments with compound (44) disclosed the cis-relationship between $\mathrm{H}-11$ and 14-OMe and thus suggested the following stereostructure for this compound (44). The 18methyl group is assigned an $\alpha$ configuration, considering the coupling constant $(J=1 \mathrm{~Hz})$ between $\mathrm{H}-12$ and $\mathrm{H}-13$ in the n.m.r. spectrum of the $\mathrm{NaBH}_{4}$ reduction product of (44). The configuration of the acetoxy group at $\mathrm{C}-7$ was suggested from the following facts: in the reaction of kansuinine A with $p$-toluenesulphonic acid leading to compound (47), the acetoxy group at C-7 is displaced by an internal $\mathrm{S}_{\mathrm{N}} 2$ mechanism, and the coupling constants $\left(J_{7,8}\right.$ and $\left.J_{8,9}\right)$ in the n.m.r. spectrum of kansuinine A are within $1 \mathrm{~Hz}$.

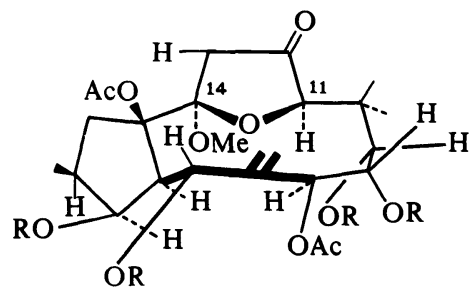

$\begin{array}{ccc}\text { Irradiated } & \text { Observed } & \text { Increase } \\ \mathrm{OCH}_{3} & \mathrm{H}-11 & 19 \% \\ \mathrm{H}-4 & \mathrm{H}-3 & 9 \% \\ & \mathrm{H}-7 & 16 \%\end{array}$

\subsection{Structure of kansuinine 5 (56)}

Kansuinine $B$ has two acetate groups and two benzoate groups as shown in the n.m.r. spectrum. Consequently, the parent alcohol is $\mathrm{C}_{20} \mathrm{H}_{30} \mathrm{O}_{10}$, a highly oxygenated diterpene. 


\subsubsection{Functional groups}

(a) Exocyclic methylene-Kansuinine B afforded a diol (57) with osmium tetroxide in pyridine followed by treatment with sodium bisulphite. The $p$-bromobenzoate (58) was obtained from (57) by the action of p-bromobenzoyl chloride in pyridine.

(b) cis-Diol and secondary alcohol-The oxidation of kansuinine B by periodic acid afforded ketoaldehyde (59). Furthermore, ketoaldehyde (59) was converted to monoacetate (60) with acetic anhydride-pyridine. From the n.m.r. spectra of these compounds, (59) and (60), the presence of partial structures $\left(\mathrm{I}^{\prime}\right),\left(\mathrm{II}^{\prime}\right),\left(\mathrm{III}^{\prime}\right)$ and $\left(\mathrm{IV}^{\prime}\right)$ was revealed.

$\left(\mathrm{I}^{\prime}\right)$<smiles>CC(O)C(C)(O)O</smiles><smiles>[R]O[C]([AlH])[C@H](C)O</smiles><smiles>[Y20]CC(=C)CC(C)C(OC)[C@@H](OC)[C@@H](C)[Hg]</smiles>

\subsection{2. $X$-Ray analysis of compound (58)}

The structure of compound (58) was unambiguously established by $\mathrm{x}$-ray analysis (Figure 4) ${ }^{37}$.

\subsubsection{The reaction of kansuinine $B$ with acid}

Kansuinine B was sensitive in acidic media. In particular, we detected compounds (61) and (62), the products formed by an acid-catalysed transannular reaction. In the n.m.r. spectrum of compound (62), the signal of the acetoxyl group at $\mathrm{C}-15$ appeared as a broad singlet at $\delta 1.90$. This phenomenon may be caused by steric crowding around the acetoxy group.

\subsubsection{The reaction of kansuinine $B$ with base}

The treatment of kansuinine B with sodium carbonate in ethanol gave compounds (63) and (64), which were acetylated to give compound (65). The $\mathrm{O}, \mathrm{O}^{\prime}$-acetyl migration from $\mathrm{C}-15$ to $\mathrm{C}-8$ followed by formation of the fivemembered ether ring is very unusual for this carbon skeleton. The driving force of this reaction may be attributed to the steric crowding of the acetyl group at C-15 caused by exocyclic methylene, the benzoate group at C-7, and the methyl group at $\mathrm{C}-13$; this was deduced with the aid of molecular models.

Kansuinines A and B are polyoxygenated diterpenes. These compounds containing the twelve-membered carbocycle with multi-functional groups are interesting not only for their physiological activities but from the viewpoint of the relationship of reactivities and conformation.

\subsection{Ingenol and 13-oxyingenol derivatives}

The following compounds (66), (67) and (68), were obtained. The ester of 13-oxyingenol which belongs to the newly discovered class of compounds, undergoes the following interesting reactions. 
YOSHIMASA HIRATA

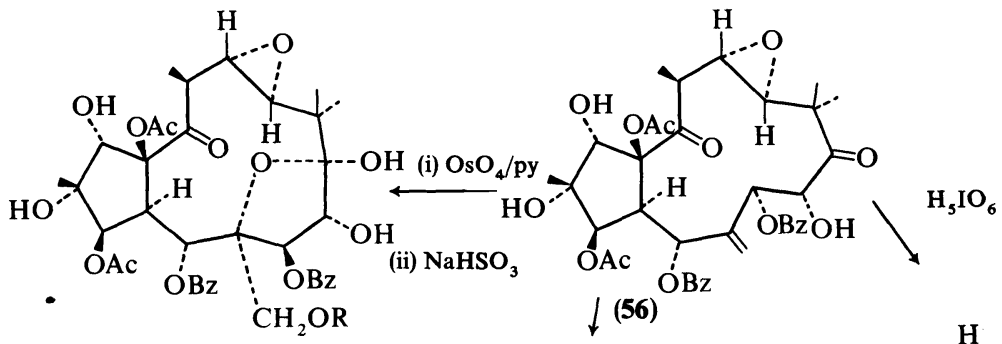

(57) $\mathrm{R}=\mathrm{H}$

(58) $\mathrm{R}=p$-bromobenzoyl

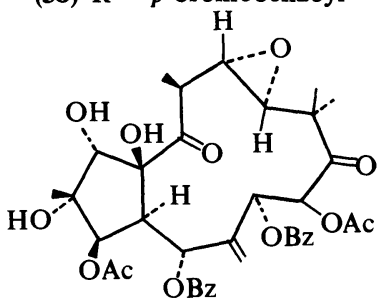<smiles>[3H][CH]</smiles>

(63) $+(64)$

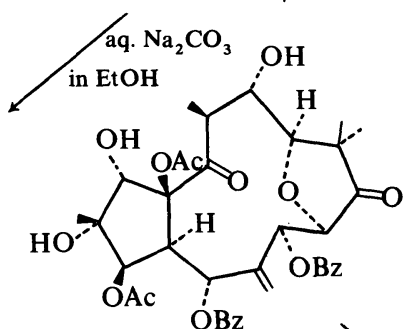

(62)

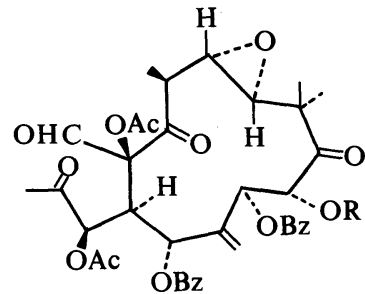

(59) $\mathrm{R}=\mathrm{H}$

(60) $\mathrm{R}=\mathrm{Ac}$

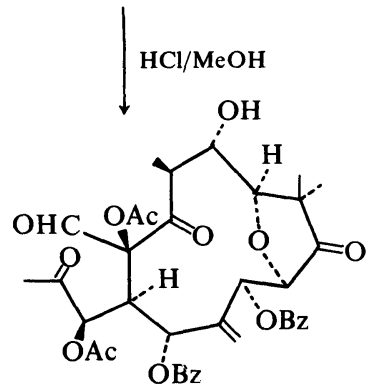

(61)

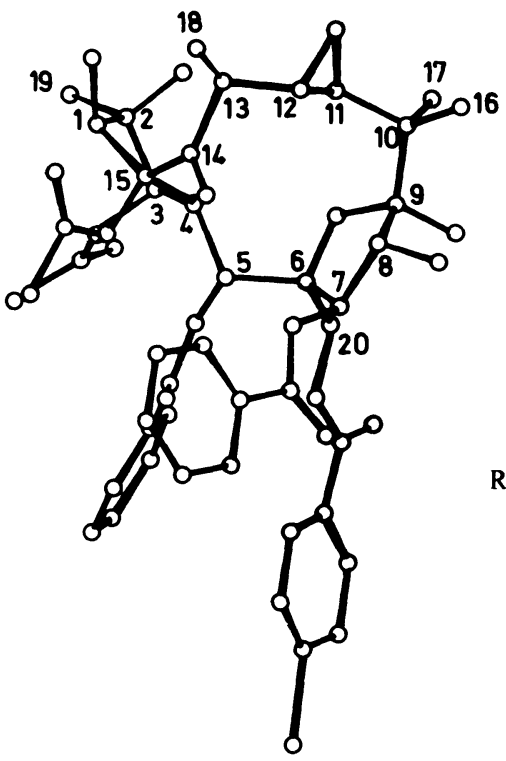

(63) $R_{1}=A c, R_{2}=H$

(64) $R_{1}=R_{2}=H$

(65) $R_{1}=R_{2}=A c$

Figure 4. The crystal structure and absolute configuration of the compound (58) have been determined by Drs C. Katayama, K. Sasaki and Mr E. Uno. The space group is $P 1$ and the lattice constants are $a=10.57 \AA, b=11.97 \AA, c=9.96 \AA, \alpha=103.3^{\circ}, \beta=104.1^{\circ}$ and $\gamma=82.2^{\circ}$. The final $R$ index for 3527 reflections is 0.07 . 
In order to obtain the parent alcohol, hydrolysis of compound (69) was tried, but this attempt was fruitless. Accordingly, the reductive cleavage of the ester group was examined, giving compound (70). The structure of compound (70) was determined by subsequent formation of the cyclooctenone system (71), which was produced by 1,3-fragmentation involving the cleavage of the cyclobutanol system of compound (70). In contrast to compound (69), simple reductive cleavage of the ester in compound (72) was achieved affording compound (73). The reason the tetramethyl ether (72) produces no cyclobutanol compound with lithium aluminium hydride may be the steric effect between the methoxy group at $\mathrm{C}-4$ and the newly produced $\mathrm{C} 9-\mathrm{C} 12$ bonding. Also formation of the unique cyclobutanol compound (74) by intramolecular aldol condensation occurred by treatment of compound (73) with potassium $t$-butoxide.

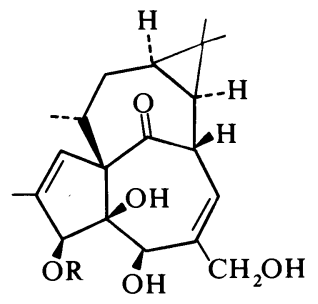

(66)

$\mathrm{R}=\mathrm{CO}(\mathrm{CH}=\mathrm{CH})_{2}\left(\mathrm{CH}_{2}\right)_{5} \mathrm{CH}_{3}$

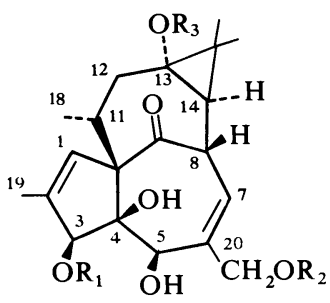

(67) $\mathrm{R}_{1}=\mathrm{CO}(\mathrm{CH}=\mathrm{CH})_{2}\left(\mathrm{CH}_{2}\right)_{5} \mathrm{CH}_{3}, \mathrm{R}_{2}=\mathrm{H}$, $\mathbf{R}_{\mathbf{3}}=$ dodecanoyl

(68) $\mathbf{R}_{1}=\mathrm{H}, \mathbf{R}_{\mathbf{2}}=$ hexanoyl, $\mathbf{R}_{\mathbf{3}}=$ dodecanoyl

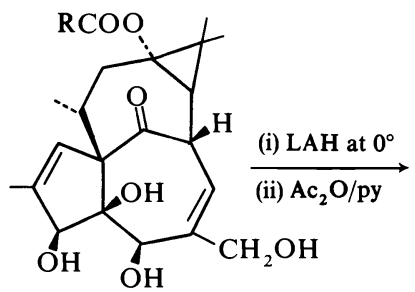

(69)

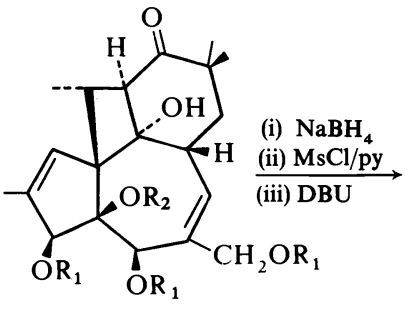

(70) $\mathrm{R}_{1}=A c, \mathrm{R}_{2}=\mathrm{H}$

(74) $R_{1}=R_{2}=M e$

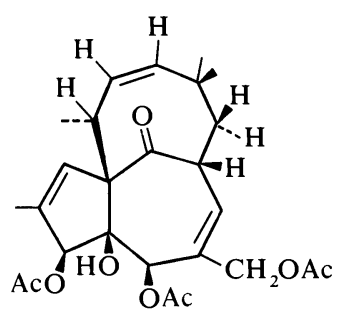

(71)

\section{$\downarrow \mathrm{MeI} / \mathrm{Ag}_{2} \mathrm{O} / \mathrm{DMF}$}

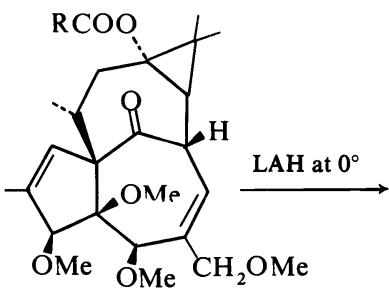

(72)

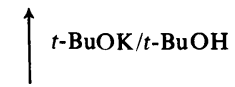

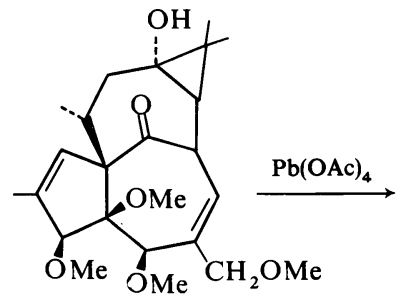

(73)

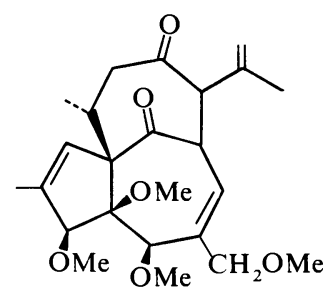

(75) 


\section{OTHER POLYOXYGENATED TOXIC NATURAL PRODUCTS}

We shall next discuss the properties of physiologically active polyoxygenated compounds other than those isolated from Euphorbiaceae: i.e. (a) Euonymus alkaloids such as evonine ${ }^{38}$, (b) Anisatin ${ }^{39}$, (c) Tetrodotoxin ${ }^{40}$.

\subsection{Euonymus alkaloids}

Ten compounds having alkaloid moieties linked to a polyoxygenated sesquiterpene skeleton have been identified.
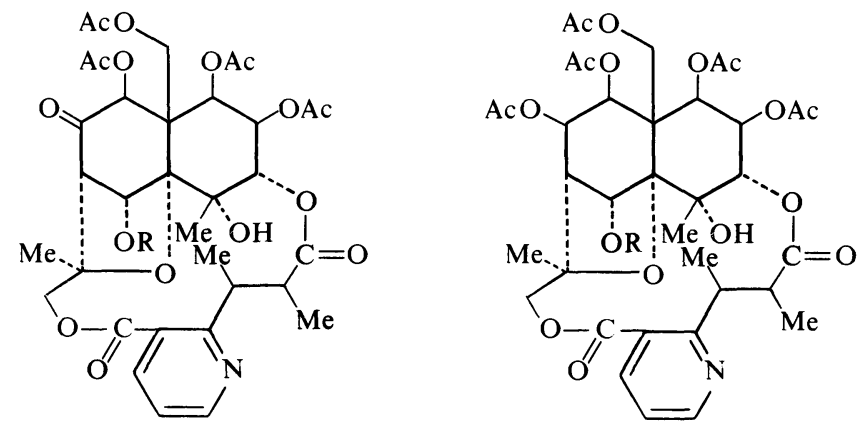

$\mathbf{R}=$ Ac Evonine

$\mathrm{R}=\mathrm{Ac}$ Euonymine

$\mathbf{R}=\mathbf{H} \quad$ Neoevonine

$\mathrm{R}=\mathrm{H} \quad$ Neoeuonymine
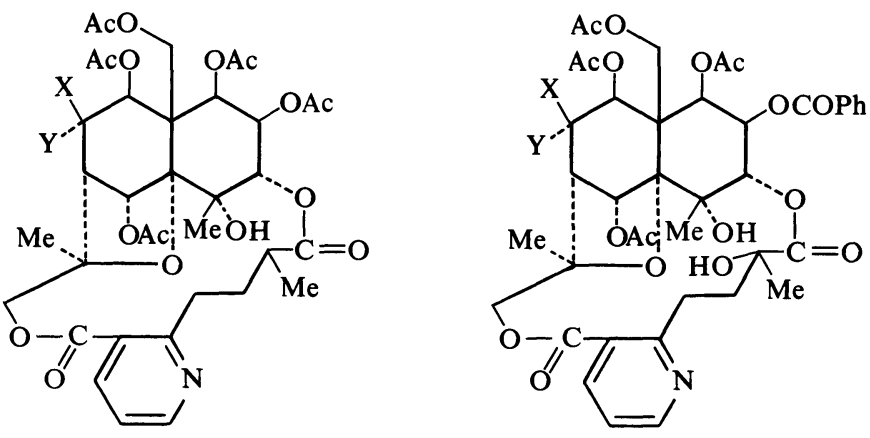

$\mathrm{X}, \mathrm{Y}=\mathrm{O}$ Evonimine

$\mathrm{X}=\mathrm{OAc}, \mathrm{Y}=\mathrm{H}$ Euonine

$\mathrm{X}, \mathrm{Y}=\mathrm{O}$ Alatamine

$\mathrm{X}=\mathrm{OAc}, \mathrm{Y}=\mathrm{H} \quad$ Wilfordine

\subsection{Anisatin and neoanisatin}

These also are polyoxygenated sesquiterpenoids and possess some interesting properties. 
TOXIC SUBSTANCES OF EUPHORBIACEAE

Base-catalysed isomerization

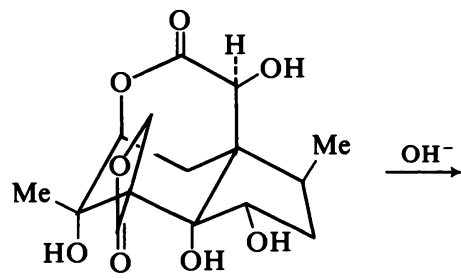<smiles>CC1CC(O)C(O)C2(C(=O)O)CCC1(C(=O)O)C(C)C(=O)O2</smiles>

Thermal isomerization

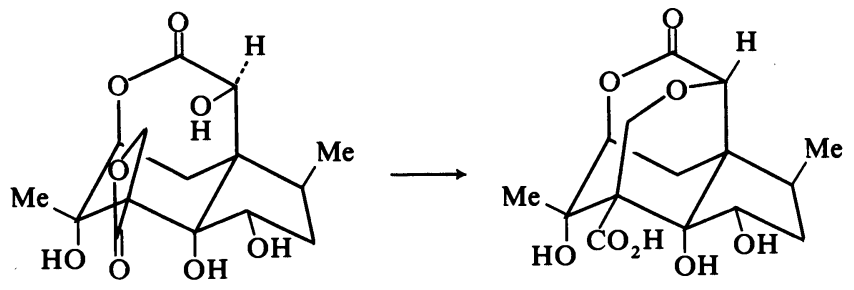

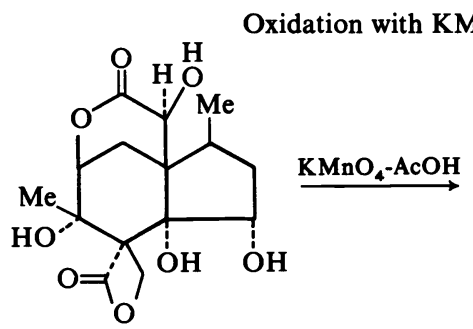

Anisatin<smiles>CC1CC(O)C2(O)C(=O)OC1CC21C(=O)OCC1(C)O</smiles>

Noranisatin

An unusual deshielding phenomenon by an acetoxyl group in n.m.r.

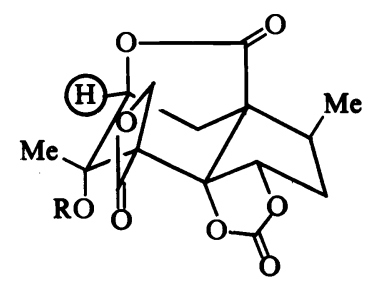

$$
\begin{array}{lll}
\mathrm{R}=\mathrm{H} & \delta 4.59(\mathrm{~d}) & \Delta \\
\mathrm{R}=\mathrm{Ac} & \delta 5.48
\end{array}
$$

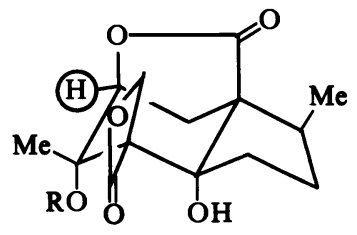

$\mathrm{R}=\mathrm{H} \quad \delta \quad 4.28$

$\mathrm{R}=\mathrm{Ac} \quad \delta 5.39$ 


\subsection{Tetrodotoxin}

This toxin isolated from the puffer fish also contains many oxygens, and it is renowned for its high neurotoxicity, $0.008 \gamma / \mathrm{g}$. The unique structure gives rise to interesting reactions.

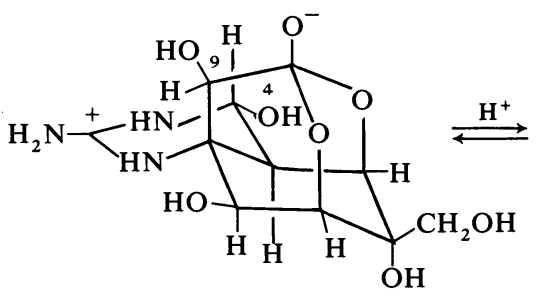

Tetrodotoxin

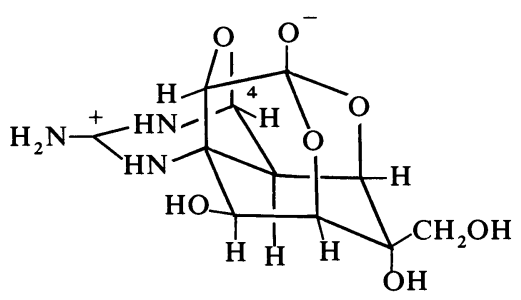

Anhydroepitetrodotoxin

\section{RELATION BETWEEN STRUCTURE AND TOXICITY}

The examples cited so far indicate that polyoxygenated compounds possess high toxicity even when the structure is relatively simple. They also possess interesting physical and chemical properties; however, the structure/ activity relationship is complex.

(1) Anisatin and neoanisatin, which contains one less $\mathrm{OH}$, have the same toxicity of the order of $1 \gamma / \mathrm{g}$, but anisatinic acid is non-toxic.

(2) Tetrodotoxin is highly toxic $(0.008 \gamma / \mathrm{g})$ but anhydroepitetrodotoxin (simple ether formation between $\mathrm{C}-9 \mathrm{OH}$ and an inverted $\mathrm{C}-4$ axial $\mathrm{OH}$ ) is non-toxic.

(3) Ingenol and its triacetate are non-toxic but its higher fatty acid esters are toxic; the toxicities of C-3 esters are high but those of the C-20 esters are weak.

As exemplified by these compounds, the structure/toxicity relation is complex and is as yet hardly understood.

\section{ACKNOWLEDGEMENT}

I would like to express my deep appreciation to my co-workers, Drs S. Yamamura and M. Toda (Daphniphyllaceae), and Drs D. Uemura, Y. P. Chen, H. Y. Hsu and C. Katayama (Euphorbiaceae).

\section{REFERENCES}

${ }^{1}$ N. Sakabe and Y. Hirata, Tetrahedron Letters, 965 (1966).

${ }^{2}$ H. Irikawa, N. Sakabe, S. Yamamura and Y. Hirata, Tetrahedron, 24, 5691 (1968).

${ }^{3}$ M. Toda, H. Niwa, Y. Hirata and S. Yamamura, Tetrahedron Letters, 797 (1973).

4 C. S. Gibbons and J. Trotter, J. Chem. Soc. (B), 840 (1969);

T. Nakano, Y. Saeki, C. S. Gibbons and J. Trotter, Chem. Commun. 600 (1968).

5 T. Nakano, M. Hasegawa and Y. Saeki, J. Org. Chem. 38, 2404 (1973).

${ }^{6}$ M. Toda, H. Niwa, H. Irikawa, Y. Hirata and S. Yamamura, Tetrahedron, in press. 
7 S. Yamamura and Y. Hirata, J. Chem. Soc. 2887 (1968);

M. Toda, M. Hayashi, Y. Hirata and S. Yamamura, Bull. Chem. Soc. Japan, 45, 264 (1972).

${ }^{8}$ M. Iguchi, M. Niwa, S. Yamamura and Y. Hirata, unpublished work.

9 H. Niwa, M. Toda, S. Ishimaru, Y. Hirata and S. Yamamura, Tetrahedron, in press.

10 K. Sasaki and Y. Hirata, J. Chem. Soc. (B), 1565 (1971);

M. Toda, Y. Hirata and S. Yamamura, Tetrahedron, 28, 1477 (1972).

$11 \mathrm{~S}$. Yamamura and Y. Hirata, unpublished works.

12 M. Toda, Y. Hirata and S. Yamamura, Chem. Commun. 1597 (1970).

13 J. O. Reed and W. Lwowski, J. Org. Chem. 36, 2864 (1971).

${ }^{14}$ M. Toda, H. Niwa, K. Ienaga, Y. Hirata and S. Yamamura, Tetrahedron Letters, 335 (1972).

15 K. Sasaki and Y. Hirata, J. Chem. Soc. Perkin Transactions II, 1411 (1972).

${ }^{16}$ K. Sasaki and Y. Hirata, Acta Cryst. B29, 547 (1973).

17 H. Sakurai, N. Sakabe and Y. Hirata, Tetrahedron Letters, 6309 (1966);

H. Irikawa, S. Yamamura and Y. Hirata, Tetrahedron, 28, 3727 (1972).

18 T. Nakano and B. Nilsson, Tetrahedron Letters, 2883 (1969).

19 S. Yamamura and Y. Hirata, unpublished works.

20 S. Yamamura, K. Sasaki, M. Toda and Y. Hirata, Tetrahedron Letters, 2023 (1974).

21 H. Sakurai, H. Irikawa, S. Yamamura and Y. Hirata, Tetrahedron Letters, 2883 (1967).

22 T. Nakano and Y. Saeki, Tetrahedron Letters, 4791 (1967).

${ }^{23}$ M. Toda, H. Irikawa, S. Yamamura and Y. Hirata, J. Chem. Soc. Japan, 91, 103 (1970).

${ }^{24}$ K. T. Suzuki, S. Okuda, H. Niwa, M. Toda, Y. Hirata and S. Yamamura, Tetrahedron Letters, 799 (1973); 2129 (1973).

25 D. Uemura and Y. Hirata, Tetrahedron Letters, 3673 (1971).

26 D. Uemura and Y. Hirata, Tetrahedron Letters, 881 (1973).

${ }^{27}$ K. Zechmeister, F. Brandl, W. Hoppe, E. Hecker, H. J. Opferkuch and W. Adolf, Tetrahedron Letters, 4075 (1970), and references cited therein.

28 The author wishes to thank Dr Maurer (Varian Mat) for FD-analysis.

29 L. Crombie, M. L. Games and D. J. Pointer, J. Chem. Soc., C, Org., 1347 (1968), and references cited therein.

${ }^{30}$ D. Uemura and Y. Hirata, unpublished work.

31 D. Uemura and Y. Hirata, Tetrahedron Letters, 1387 (1972).

32 D. Uemura and Y. Hirata, Chemistry Letters, in press (1974).

33 D. Uemura, Y. Hirata, Y. P. Chen and H. Y. Hsu, Tetrahedron Letters, in press (1974).

34 D. Uemura, H. Ohwaki, Y. Hirata, Y. P. Chen and H. Y. Hsu, Tetrahedron Letters, in press (1974).

35 D. Uemura, Y. Hirata, Y. P. Chen and H. Y. Hsu, unpublished work.

36 The author wishes to thank Dr R. Stevenson (Varian Aerograph) for the discussion about HPLC.

37 D. Uemura, Y. Hirata, C. Katayama, K. Sasaki and E. Uno, unpublished works.

38 Y. Shizuri, H. Wada, K. Sugiura, K. Yamada and Y. Hirata, Tetrahedron, 29, 1773 (1973).

39 K. Yamada, S. Takada, S. Nakamura and Y. Hirata, Tetrahedron, 24, 199 (1968).

40 T. Goto, Y. Kishi, S. Takahashi and Y. Hirata, Tetrahedron, 21, 2059 (1965). 